\title{
PENGARUH KUALITAS PRODUK, HARGA DAN LOKASI TERHADAP KEPUTUSAN PEMBELIAN KOPI PADA COFFE SHOP KOMUNAL
}

\author{
M. Fatihadi Rahmanto Wibowo ${ }^{1}$, Rusminah $\mathrm{HS}^{2}$ \\ ${ }^{1}$ Universitas Mataram, Mataram: wibywiby4@gmail.com \\ ${ }^{2}$ Universitas Mataram, Mataram: rosewahyu99@gmail.com
}

\begin{tabular}{|c|c|c|c|}
\hline \multicolumn{4}{|l|}{ Article history } \\
\hline $\begin{array}{l}\text { Dikirim tanggal } \\
\text { Revisi pertama tanggal }\end{array}$ & $\begin{array}{l}: 03 / 02 / 2021 \\
: 13 / 08 / 2021\end{array}$ & $\begin{array}{l}\text { Diterima tanggal } \\
\text { Tersedia online tanggal }\end{array}$ & $\begin{array}{ll}: & 16 / 08 / 2021 \\
: & 07 / 09 / 2021\end{array}$ \\
\hline
\end{tabular}

\begin{abstract}
ABSTRAK
Tujuan penelitian ini yaitu untuk mengetahui apakah faktor produk,harga, dan lokasi terhadap keputusan pembelian kopi pada Coffee Shop Komunal . Untuk memperoleh data yang diperlukan dalam penelitian ini, penulis menggunakan tehnik wawancara, dan angket. Jumlah sampel yang digunakan pada penelitian ini adalah 70 orang responden. Metode pengumpulan data yang digunakan adalam sample survey. Metode analisis data yang digunakan adalah regresi linier berganda. Dari hasil analisis, diperoleh hasil persamaan regresi sebagai berikut, $\mathrm{Y}=1.380 \mathrm{X} 1+0,141 \mathrm{X} 2+0,595 \mathrm{X} 3+0,175$. Dari hasil analisis diketahui bahwa variabel kualitas produk dan harga memiliki pengaruh positif dan signifikan, sedangkan lokasi memiliki pengaruh yang positif dan tidak signifikan terhadap keputusan pembelian kopi pada Coffee Shop Komunal. Nilai koefisien determinasi (adjusted R2 ) yang diperoleh sebesar 0,805. Hal ini berarti 80,5\% keputusan pembelian dapat dijelaskan oleh variabel Produk, Harga, dan Lokasi, sedangkan 19,5\% keputusan pembelian dapat dijelaskan dari variabel lain selain ketiga variabel tersebut.
\end{abstract}

Kata kunci : Produk, Harga,Lokasi, Keputusan Pembelian.

\section{ABSTRACT}

The purpose of this study is to determine the three factors quality product, price, and location influence on the purchase decision coffee at the Communal coffee shop. To obtain the necessary data for this study, the researcher used interview and questionnaire. The number of samples of this study were 70 respondents. The data collection method employed was the sample survey. The data analysis method used was multiple linear regression. The research results that have regression equation: $Y=1.380 X 1+$ $0.141 X 2+0.595 X 3+0.175$. The result analisys the three variables, quality product, and prace have a positive and significant influence, but location have positive and not significant influence on the purchase decision coffee at the Communal Coffee Shop. The coefficient of determination (adjusted R2) obtained was 0.805. This means that product, price and location variables accounted for the purchase decision. Meanwhile, 19.5\% of purchase decisions can be the influence of variables other than these three variables.

Keyword : Product, Prece, Location, Purchase Decision. 


\section{PENDAHULUAN}

Keinginan manusia terus berkembang dan tidak terbatas seiring dengan perkembangan zaman. Manusia tidak lagi mampu untuk memenuhi kebutuhan dan keinginannya sendiri sehingga diperlukan adanya organisasi yang dapat memenuhi kebutuhan dan keinginan tersebut. Dunia bisnis terus berkembang pesat sejalan dengan perkembangan era globalisasi, hal ini ditandai dengan semakin tingginya tingkat persaingan di dunia bisnis dalam memasarkan produk maupun jasa kepada konsumen. Para pelaku bisnis saling berlomba-lomba dalam memasarkan produk yang mereka tawarkan dalam rangka memenuhi kebutuhan dan keinginan konsumen.

Secara umum saat ini konsumen lebih memilih produk yang berharga murah namun memiliki kualitas yang baik, oleh sebab itu dalam kondisi persaingan yang sangat tinggi, perusahaan harus mampu memahami dan mengetahui keinginan dan kebutuhan konsumenya dan terus berinovasi untuk menciptakan positioning produknya dengan baik dan memanfaatkan keunggulan-keunggulan yang ada pada produk yang ditawarkan. Menurut Cravens dalam Prasetijo dan Ihalauw (2005:4), perusahaan yang gagal memahami kebutuhan, keinginan, selera dan proses keputusan pembelian konsumen akan mengalami kegagalan dalam pemasaran dan penjualannya.

Persaingan yang ketat didalam dunia bisnis terjadi pada berbagai bidang, termasuk bisnis kuliner. Kebutuhan akan makanan dan minuman merupakan kebutuhan dasar manusia yang wajib terpenuhi sehingga bisnis kuliner menjadi trend dikalangan masyarakat Indonesia. Beberapa tahun terakhir, jumlah bisnis kuliner di Indonesia terus bertambah dengan beragam variasi produk yang ditawarkan, hal ini dipengaruhi oleh terjadinya perubahan pola konsumsi dan perubahan gaya hidup konsumen Indonesia.

Pola konsumsi masyarakat Indonesia berubah dari makanan tradisional ke makanan moderen dan perubahan gaya hidup yang cenderung lebih memilih sesuatu yang sifatnya praktis seperti halnya mengkonsumsi makanan siap saji. Peluang inilah yang dimanfaatkan oleh para pelaku bisnis untuk ikut terjun ke dalam bisnis kuliner dengan berlomba-lomba dalam memenuhi kebutuhan dan keinginan konsumen dengan produk yang mereka tawarkan sehingga membuat persaingan di dunia bisnis kuliner menjadi semakin ketat yang menyebabkan semakin banyak pula pilihan bagi konsumen dalam memilih produk yang dapat memuaskan kebutuhannya sehingga konsumen akan lebih selektif dalam membuat sebuah keputusan pembelian.

Keputusan pembelian merupakan suatu keputusan sebagai pemilihan suatu tindakan dari dua atau lebih pilihan alternatif (Sumarwan. 2011:12). Pada pengambilan keputusan pembelian, konsumen selalu mempertimbangkan faktor- faktor yang ada seperti harga, lokasi dan kualitas produk yang didapatkan.

Namun, hal penting yang harus dipahami oleh organisasi bisnis bahwa setiap konsumen memiliki perilaku yang berbeda sehingga harus mengetahui. Perilaku konsumen adalah proses yang terjadi pada konsumen ketika memutuskan membeli, apa yang dibeli, di mana dan bagaimana membelinya (Kotler,2005).

Di Lombok khususnya Kota Mataram sendiri sudah banyak ditemui Coffee shop dengan berbagai konsep dan menu yang ditawarkan. Salah satunya yaitu Coffe shop Komunal menyediakan beragam kopi yang berkualitas premium dari bermacam daerah yang berada di Indonesia. Komunal juga menyediakan menu minuman lain selain kopi, seperti tea, sam brewok coffe beer, kopi susu alpukat, matcha, kopi susu, latte dll, salah satu minuman andalan Komunal adalah Kopi susu alpukat. Serbuk alpukat dituang ke gelas lalu ditambah es batu yang terbuat dari kopi dan disajikan dengan sebotol susu segar. Komunal pertama kali didirikan Tahun 2017 di Lombok 
Kota Mataram, Jalan Arif Rahman No.47 yang berada di pusat kota dan letak lokasi yang sangat mudah di temukan oleh konsumen.

Komunal merupakan suatu coffe shop yang sudah banyak di ketahui oleh masyarkat karna menu andalannya dan lokasi yang sangat mudah dan di tengah keramaian kota Mataram. Dan konsumen yang mengujungi adalah mahasiswa dan remaja. Rata-rata konsumen di Komunal berkisaran antara 30 hingga 50 orang perharinya dengan kedai coffe yang bisa dibilang mini. Ramainya konsumen di Komunal menjadi hal yang menarik untuk di teliti, melihat banyaknya pesaing sejenis di daerh tersebut. Di Lombok sendiri, terdapat coffe shop dengan keunggulan produknya dan lokasi yang mewah dan besar masing-masing yang saling bersaing untuk meraih konsumen. Jumlah bisnis coffee shop di daerah Lombok khususnya di Kota Mataram juga terus bertambah seiring dengan perkembangan waktu sehingga membuat persaingan menjadi semakin ketat. Berikut ini merupakan beberapa pesaing di Lombok khususnya Kota Mataram.

Tabel 1.

Daftar Nama Coffe Shop Di Kota Mataram

\begin{tabular}{cll}
\hline No. & \multicolumn{1}{c}{ Nama Coffee shop } & \multicolumn{1}{c}{ Alamat } \\
\hline 1. & Maktal coffe Bar & J1.Maktal no 3 Cakranegara,Mataram \\
2. & Kopi janji jiwa & Jl. Sriwijaya No.401B, Punia \\
3. & Kopi soe & J1.A. A Gede Ngurah No.48-234, Cilinaya \\
4. & Benas coffe & J1.Saleh Sungkar No.22 Dayan peken \\
5. & Waroeng ngawak & Jl.Adi Sucipto No.12a, Ampenan Utara \\
\hline
\end{tabular}

Sumber: Google.Coffeeshop di Kota Mataram 2016

Nama Komunal berasal dari KBBI yaitu kepemilikan Bersama, Akbar pengusaha lokal yang melanjutkan bisnis kopi dari pengalamnya berkerja bersama orang dan mengelilingi coffe shop. Ia ingin menyalurkan pengalamnya dan kecintaannya kepada kopi. Itulah sebabnya mengapa komunal berfokus pada minuman. Komunal sendiri mengexplor biji kopi yang berasal dari berbagai macam daerah yang berkualitas tinggi. Komunal menawarkan menu yang bervariasi dengan kualitas dan rasa yang baik serta tampilan yang unik, sesuai dengan harga yang ditawarkan kepada konsumen. Harga yang ditawarkanpun relatif terjangkau dan bersaing dengan Coffee shop lainnya, dimulai dengan harga Rp. 13.000 sampai dengan Rp. 55.000. Strategi ini dilakukan oleh pihak Komunal agar produknya dapat dinikmati oleh berbagai kalangan. Kualitas produk yang diberikan oleh Komunal tidak diragukan lagi karena Komunal menyajikan berbagai pilihan premium biji kopi gourmet dari berbagai daerah di seluruh Indonesia. Biji kopi Komunal adalah 100\% murni dengan biji kopi terbaik premium di seluruh Indonesia sehingga Komunal memiliki cita rasa yang khas. Komunal memiliki beragam variasi menu yang ditawarkan kepada konsumen dengan tampilan yang unik dan rasa yang Berdasarkan uraian diatas, maka peneliti tertarik untuk melakukan penelitian dengan judul "PENGARUH KUALITAS PRODUK, HARGA DAN LOKASI TERHADAP KEPUTUSAN PEMBELIAN KOPI PADA COFFE SHOP KOMUNAL “" 


\section{TINJAUAN TEORITIS}

\section{Kualitas Poduk}

Konsumen menginginkan kualitas produk yang baik dengan harga yang murah. Produk maupun jasa yang dijual harus memiliki kualitas yang baik atau sesuai dengan harga yang ditawarkan. Agar suatu usaha atau perusahaan dapat bertahan dalam menghadapi persaingan, terutama persaingan dari segi kualitas, perusahaan perlu meningkatkan kualitas produk atau jasanya.

Menurut Kotler dan Amstrong (2009:4) produk adalah segala sesuatu yang dapat ditawarkan kepasar untuk mendapatkan perhatian, dibeli, digunakan, atau dikonsumsi yang dapat memuaskan keinginan atau kebutuhan.

Menurut Kotler dan Keller (2008:) bahwa kualitas adalah keseluruhan ciri- ciri dan karakteristik dari suatu barang atau jasa, dalam hal kemampuan untuk memenuhi kebutuhan-kebutuhan yang dinyatakan atau tersirat. Menurut Kotler dan Armstrong (2012:283) kualitas produk adalah karakteristik produk atau jasa yang bergantung pada kemampuannya untuk memuaskan kebutuhan pelanggan yang dinyatakan atau diimplikasikan.

Kualitas produk menjadi salah satu tolak ukur penting bagi kesuksesan sebuah perusahaan, karena dengan kualitas produk yang baik, perusahaan akan mampu bersaing dengan para pesaingnya. Perusahaan juga harus melakukan inovasi- inovasi baru terhadap produk yang mereka tawarkan karena konsumen cenderung bersikap kritis terhadap produk-produk yang beredar di pasaran.

Persepsi konsumen terhadap kualitas produk, dapat dipengaruhi oleh harga produk. Konsumen memiliki persepsi, apabila semakin tinggi harga suatu produk maka semakin tinggi pula kualitas dari produk tersebut. Konsumen dapat mempunyai persepsi seperti itu ketika mereka tidak memiliki petunjuk atau acuan lain dari kualitas produk, selain harga produk, namun sebenarnya persepsi kualitas suatu produk dapat dipengaruhi pula oleh reputasi toko, iklan, dan variabel- variabel lainnya.

\section{Indikator Kalitas Produk}

Menurut Stanton (2006, p. 222), yang dimaksud dengan produk adalah "Sekumpulan atribut yang tangible (nyata) dan intangible (tidak nyata) di dalamnya sudah tercakup warna, harga, kemasan, prestise pabrik, prestise pengecer, dan pelayanan dari pabrik serta pengecer, yang mungkin diterima oleh pembeli sebagai sesuatu yang bisa memuaskan keinginannya."'Intinya pada dasarnya manusia rela membayar sesuatu yang dapat memuaskan keinginannya.Jadi perusahaan yang bijak menjual manfaat (benefit) produk tidak hanya berupa produk itu semata. Sedangkan menurut Bennion dan Scheulle (2004,pp. 11-18) karakteristik dari makanan adalah faktor penentu yang paling penting saat mencoba menikmati suatu makanan, diantaranya adalah :

Penampilan menciptakan kesan terhadap suatu makanan, contohnya warna, porsi, desain. Kesegaran suatu makanan paling sering tampak dari penampilan makanan itu sendiri.

1. Selera Flavor

Selera Flavor adalah atribut penting dari suatu makanan yang merupakan campuran dari rasa, bau, sensai yang ditimbulkan oleh bahan makanan.

2. Rasa

Rasa adalah sensasi yang diterima saat makanan berada di mulut. Rasa primer meliputi manis, asin, asam, dan pahit. 
3. Tekstur

Tekstur adalah bagian-bagian dari minuman itu sendiri yang menunjukan sebuah struktur, misalnya tekstur dari sebuah kopi atau tekstur dari rasa yang melekat,dan lain-lain.

\section{Harga}

Harga produk atau jasa yang dipasarkan merupakan faktor yang sangat penting. Harga suatu barang atau jasa merupakan salah satu faktor yang menjadi pertimbangan bagi konsumen sebelum melakukan keputusan pembelian. Harga jual akan menentukan kedudukan perusahaan pada pasar persaingan, di dalam persaingan usaha yang semakin ketat sekarang ini dan semakin banyaknya usaha- usaha baru yang bergerak di bidang yang sama atau hampir sama, menuntut perusahaan dapat menentukan harga terhadap produk atau jasa yang mereka jual dengan tepat. Persaingan harga sangat mempengaruhi bertahan atau tidaknya suatu perusahaan menghadapi para pesaingnya.

Menurut Kotler dan Keller (2008:345), harga adalah jumlah uang yang harus dibayar pelanggan untuk produk itu, sedangkan menurut Kotler \& Amstrong (2012), harga merupakan sejumlah uang yang dibebankan atas suatu produk atau jasa atau jumlah dari nilai yang ditukar konsumen atas manfaat-manfaat karena memiliki atau menggunakan produk atau jasa tersebut.

Pada umumnya penjual mempunyai beberapa tujuan dalam penetapan harga produknya. Tujuan tersebut antara lain:

1. Mendapatkan laba maksimum.

2. Mendapatkan pengembalian investasi yang ditargetkan atau pengembalian pada penjualan bersih.

3. Mencegahatau mengurangi persaingan

Harga merupakan salah satu faktor penentu konsumen dalam menentukan suatu keputusan pembelian terhadap suatu produk maupun jasa. Terutama apabila produk atau jasa yang akan dibeli tersebut merupakan kebutuhan sehari-hari seperti makanan, minuman dan kebutuhan pokok lainnya, konsumen akan sangat memperhatikan harganya. Pengusaha perlu untuk memperhatikan hal ini, karena dalam persaingan usaha, harga yang ditawarkan oleh pesaing bisa lebih rendah dengan kualitas yang sama atau bahkan dengan kualitas yang lebih baik. Hal ini menyebabkan dalam penentuan harga produk atau jasa yang dijual, baik perusahaan besar maupun usaha kecil sekalipun harus memperhatikan konsumen dan para pesaingnya.

Konsumen dalam melakukan pembelian, faktor harga merupakan faktor yang lebihdulu diperhatikan, kemudian disesuaikan dengan kemampuannya sendiri. Harga dapat diklasifikasikan menjadi tiga, yaitu: mahal, sedang, dan murah.

\section{Indikator Harga}

Bahwa persepsi harga yaitu suatu penilaian seseorang tentang harga dari suatu produk yang dapat menimbulkan persepsi tersendiridan kemudian melakukan penilaian terhadap produk tersebut.

Zeithaml, Bitner, dan Gremler (2007,p.26) mengklasifikasikan harga menjadi empat variabel, yaitu :

1. Flexibility

Fleksibilitas dapat digunakan dengan menetapkan harga yang berbeda pada pasar yang berlainan atas dasar lokasi geografis, waktu penyampaian atau pengiriman atau kompleksitas produk yang diharapkan. 
2. Price Level

Diklasifikasikan menjadi tiga tingkatan yaitu penetapan harga di atas pasar, sama dengan pasar atau di bawah harga pasar.

3. Discount

Diskon merupakan potongan harga yang diberikan dari penjual kepada pembeli sebagai penghargaan atas aktivitas tertentu dari pe 5 'mbeli yang menyenangkan bagi penjual.

4. Allowance

Sama seperti diskon, allowance juga merupakan pengurangan dari harga menurut daftar kepada pembeli karena adanya aktivitas-aktivitas tertentu.

\section{Lokasi}

Lokasi merupakan salah satu faktor penting yang akan mempengaruhi konsumen dalam melakukan pembelian. Pengambilan lokasi yang baik dan strategis ialah berada di pusat kegiatan masyarakat. Lokasi yang dipilih haruslah mampu mengalami pertumbuhan ekonomi sehingga usahanya dapat bertahan.

Dalam memilih lokasi untuk menjalankan suatu usaha, para pengusaha/pelaku usaha perlu mempertimbangkan beberapa faktor, diantaranya :

1. Akses yaitu kemudahan untuk menjangkau.

2. Visibilitas yaitu kemudahan untuk dilihat.

3. Lalu lintas, ada 2 hal yang perlu diperhatikan yaitu banyaknya orang yang lalu lalang bisa memberikan peluang yang besar tejadinya impuls buying dan kepadatan serta kemacetan bisa menjadi hambatan.

4. Tempat parkir yang luas dan aman.

5. Ekspansi yaitu tersedia tempat yang luas untuk perluasan di kemudian hari.

6. Lingkungan yaitu daerah sekitar yang mendukung jasa yang ditawarkan.

7. Persaingan yaitu lokasi dengan pesaing sejenis.

8. Peraturan pemerintah (Tjiptono. 2008).

Kotler dan Keller (2009) mengartikan lokasi sebagai sarana aktivitas perusahaan agar produk mudah didapatkan oleh konsumen sasarannya, sedangkan Effendy (2008) berpendapat bahwa yang perlu mendapat perhatian dalam hal lokasi ini meliputi banyak hal (saluran distribusi, persediaan dan transport) termasuk didalamnya tempat perusahaan beroperasi, berproduksi maupun cara penyampaian barang dari produsen kepada konsumen.

\section{Indikator Lokasi}

Menurut Mischitelli (2000, p.2) elemen-elemen yang mempengaruhi pemilihan sebuah lokasi restoran adalah :

1. Place adalah hal-hal yang berhubungan dengan letak maupun posisi. Sebaiknya letak sebuah restoran dekat dengan pusat keramaian atau dekat dengan daerah yang padat penduduknya.

2. Parking, restoran sebaiknya mempunyai tempat parkir sendiri atau menggunakan tempat parkir umum yang luas, nyaman, dan aman baik untuk kendaraan roda dua maupun roda empat.

3. Accesibility, restoran seharusnya berada di jalan yang mudah untuk mencapainya, baik dengan kendaraan pribadi maupun dengan transportasi umum.

4. Visibility, bangunan dari restoran tersebut sebaiknya mudah dilihat dan diketahui banyak orang. 
5. Infrastructure, bagian ini menyangkut keseluruhan bagian gedung dimana sebuah restoran beroperasi, misalnya fasilitas umum, transportasi, dan lain-lain.

\section{Keputusan Pembelian}

Keputusan pembelian merupakan keputusan konsumen untuk membeli suatu produk setelah sebelumnya memikirkan tentang layak tidaknya membeli produk itu dengan mempertimbangkan informasi-informasi yang ia ketahui dengan realitas tentang produk itu setelah ia menyaksikannya. Setiap konsumen melakukan berbagai macam keputusan tentang pencarian, pembelian, penggunaan beragam produk dan jasa. Keputusan pembelian merupakan hal yang lazim dipertimbangkan konsumen dalam proses pemenuhan kebutuhan akan barang maupun jasa. Sebuah keputusan pembelian terjadi melalui proses perilaku yang terdiri dari lima tahap yaitu pengenalan masalah, pencarian informasi, evaluasi terhadap alternatif-alternatif, keputusan membeli dan kemudian hasil atau perilaku pembeli. Kelima tahap ini menunjukkan bahawa proses pembelian dimulai jauh dari sebelumnya saat dilaksanakannya pembelian dan memiliki konsekuensi jauh setelah pembelian (Kotlerdan Amstrong. 2012:227).

\section{Indikator Keputusan Pembelian}

Hsu dan Chang (2008:223) mengemukakan indikator untuk mengukur keputusan pembelian sebagai berikut:

1. Keinginan untuk menggunakan produk

2. Keinginan untuk membeli produk

3. Memprioritaskan pembelian suatu produk

4. Kesediaan untuk berkorban (waktu, biaya, dan tenaga) mendapatkan suatu produk.

\section{Hubungan Antar Variabel \\ Hubungan Kualitas Produk Terhadap Keputusan Pembelian}

Konsumen dalam melakukan keputusan pembelian selalu mempertimbangkan hal yang berhubungan dengan kualitas dari produk yangakan dibeli. Kualitas produk dapat diartikan kemampuan dari produk untuk menjalankan fungsinya yang mencakup daya tahan, kehandalan atau kemajuan, kekuatan, kemudahan dalam pengemasan dan reparasi produk dan ciri-ciri lainnya. Pada saat konsumen akan mengambil suatu keputusan pembelian, variabel kualitas produk merupakan pertimbangan paling utama, terutama untuk kebutuhan pokok seperti makanan dan minuman. Seperti yang dikemukan oleh Tedjakkusuma , Hartini dan Muryani (2008), dimana untuk produk yang merupakan kebutuhan pokok seperti makanan dan minuman, konsumen sangat mempertimbangkan kualitasnya, karena merupakan kebutuhan pokok dan sangat berhubungan dengan kesehatan manusia, maka kualitas produk sangat mempengaruhi konsumen dalam mengambil keputusan pembelian produk. karena produk adalah tujuan utama bagi konsumen untuk memenuhi kebutuhannya.

Hal ini diperkuat dengan beberapa penelitian yang telah dilakukan oleh Triwahyuni (2017) yang bertujuan untuk mengetahui pengaruh kualitas produk, harga, dan promosi terhadap keputusan pembelian hp OPPO pada mahasiswa Fakultas Ekonomi UN PGRI Kediri. Hasil penelitian ini menunjukkan bahwa secara parisal maupun simultan kualitas produk, harga, dan promosi berpengaruh secara signifikan terhadap keputusan pembelian.

Intan Sherlin (2017) yang bertujuan untuk mengetahui Pengaruh Kualitas Produk dan Citra Merk Terhadap Keputusan Pembelian Smartphone Samsung (Studi 
pada Mahasiswa Stie Sakti Alam Kerinci) baik secara parsial maupun secara simultan pada mahasiswa Sekolah Tinggi Ilmu Ekonomi (STIE) Sakti Alam Kerinci Sungai Penuh. Hasil dalam penelitian ini adalah pengaruh kualitas produk dan citra merk berpengaruh positif dan signifikan terhadap keputusan pembelian Smarphone Samsung pada mahasiswa STIE Sakti Alam Kerinci Sungai Penuh.

Muhibbur Ridha (2015) bertujuan untuk mengetahui pengaruh harga dan kualitas produk terhadap keputusan pembelian smartphone xiaomi di kota Banda Aceh dengan word of mouth sebagai mediasi. Hasil penelitian ini menunjukkan bahwa harga berpengaruh positif dan signifikan terhadap word of mouth, kualitas produk berpengaruh positif dan signifikan terhadap word of mouth, harga berpengaruh positif dan signifikan terhadap keputusan pembelian, kualitas produk berpengaruh positif dan signifikan terhadap keputusan pembelian, word of mouth berpengaruh positif dan signifikan terhadap keputusan pembelian, harga berpengaruh positif dan signifikan terhadap keputusan pembelian dengan word of mouth sebagai mediasi, serta kualitas produk berpengaruh positif dan signifikan terhadap keputusan pembelian dengan word of mouth sebagai mediasi.

\section{H1 : Kulitas produk berpengaruh terhadap keputusan Pembelian kopi pada Coffe shop Komunal.}

\section{Hubungan Harga dengan Keputusan Pembelian}

Menurut Swastha (1997:122), terdapat beberapa faktor yang mempengaruhi konsumen dalam memilih toko/penjual. Motif ini sering menjadi latar belakang pembelian konsumen.Faktor-faktor tersebut antara lain lokasi penjual yang strategis, harga, penggolongan barang, servis yang ditawarkan, toko yang menarik, dan kemampuan tenaga penjualnya.

Harga memiliki dua peranan utama dalam proses pengambilan keputusan para pembeli, yaitu (Tjiptono, 1997:152):

1. Peranan alokasi dari harga, yaitu fungsi harga dalam membantu para pembeli untuk memutuskan cara memperoleh manfaat dan utilitas tertinggi yang diharapkan berdasarkan daya belinya.

Peran alokasi dari harga ini akan mempengaruhi konsumen dalam pengambilan keputusan pembelian suatu produk. Berdasarkan peran dari alokasi harga tersebut, konsumen dapat mempertimbangkan terlebih dahulu produk mana yang dapat memberikan manfaat dan keuntungan yang lebih tinggi dan sesuai dengan daya belinya dari berbagai jenis produk yang ada.

2. Peranan informasi dari harga, yaitu fungsi harga dalam „mendidik ${ }^{\text {ee }}$ konsumen mengenai faktor-faktor produk, seperti kualitas.

Peran informasi dari harga akan memberikan informasi yang dibutuhkan konsumen dalam melakukan evaluasi terhadap suatu produk sebelum melakukan pengambilan keputusan pembelian. Harga mencerminkan kualitas suatu produk, sehingga penetapan harga yang tinggi dapat menyakinkan konsumen bahwa produk tersebut memiliki kualitas yang lebih baik.

Hal ini di perkuat dari beberapa peneliatan yang telah di lakukan Junio Andreti, Nabila H Zhafira Vol. 2, No. 6, 2013,72-78 The Analysis of Product, Price, Place, Promotion and Service Quality on Customers' Buying Decision of Convenience Store: A Survey of Young Adult in Bekasi, West Java, Indonesia Hasil yang didapatkan bahwa seluruh variable independent berpengaruh positif terhadap keputusan pembelian dan sebagian besar pelanggan datang ke toko karena harga yang ditawarkan, jenis promosi, dan juga kualitas layanan yang 
disediakan. Harga merupakan variable yang paling berpengaruh terhadap keputusan pembelian.

Owusu Alferd ISSN 2222-1905 (paper) Vol. 5, No.1, 2013,179-199

Influences of price and quality on consumer purchase of mobile phone in the kumasi metropolis in ghana a comparative study. Hasil yang didapatkan dari analisis tersebut sebagai berikut, $\mathrm{Y}=0.017 \mathrm{X} 1+0.311 \mathrm{X} 2$ dimana variabel kualitas produk sangat mempengaruhi konsumen dalam melakukan keputusan pembelian, kemudian diikuti oleh variabel harga .

H2 : Harga berpengaruh terhadap keputusan Pembelian kopi Coffee Shop Komunal.

\section{Hubungan Lokasi dengan Keputusan Pembelian}

Pemilihan lokasi usaha oleh suatu perusahaan akan mempengaruhi risiko (risk) dan keuntungan (profit) perusahaan tersebut secara keseluruhan. Kondisi ini terjadi karena lokasi sangat mempengaruhi biaya tetap (fix cost) maupun biaya variabel (variable cost), baik dalam jangka menengah maupun jangka panjang.

Menurut Pratiwi (2010:15) Keputusan penentuan lokasi suatu perusahaan sering bergantung kepada tipe/bentuk dari bisnis atau usaha yang akan dijalankan. Untuk menentukan lokasi suatu industri Properti, manajemen perusahaan biasanya menggunakan pendekatan biaya (cost) dengan strategi minimisasi biaya. Aktivitas ekonomi atau perusahaan cenderung untuk berlokasi pada pusat kegiatan sebagai usaha untuk mengurangi ketidakpastian dalam keputusan yang diambil guna meminimumkan risiko. Dalam hal ini, baik kenyamanan (amenity) maupun keuntungan aglomerasi merupakan faktor penentu lokasi yang penting, yang menjadi daya tarik lokasi karena bagaimanapun juga menghasilkan konsentrasi industri dan aktivitas lainnya.

Pemilihan dan penentuan lokasi untuk properti perumahan bagi setiap orang berbeda-beda sesuai dengan pertimbangan masing-masing individunya, menurut Richadson dalam Rahma (2010:39) Secara sederhana diartikan sebagai adanya trade off aksesibilitas terhadap ruang yang dipilih rumah tangga sebagai lokasi untuk properti perumahan. hal ini juga mengasumsikan bahwa kota melingkar dengan sebuah pusat tenaga kerja dan transportasi yang tersedia dimana-mana, semua lokasi dipertimbangkan secara homogen kecuali jarak ke pusat kota. Rumah tangga akan bersedia membayar lebih untuk properti dengan lokasi yang lebih dekat dengan pusat kota karena biaya commuting lebih rendah.

Hal ini di perkuat dari beberapa peneliatan yang telah di lakukan Simon Kanoga, Reuben Njugana, Shadrack Bett Vol. 1, No. 4,381-190 The Effect Of Place On Performance Of Shopping Malls In Nairobi Country Kenya Hasil yang didapatkan dari analisis tersebut sebagai berikut, $\mathrm{Y}=1.667+1.595$

X2 dimana variabel lokasi memiliki pengaruh yang besar terhadap keputusan pembelian konsumen.

Mariska Deasy Paramitha, Imroatul Khasanah Vol. 4, No. 2,2015,1-10 Analisis Pengaruh Kualitas Produk, Harga dan Lokasi Terhadap Keputusan Pembelian (Studi Pada Konsumen Mie Nges-Nges Banyumanik Semarang) Hasilnya membuktikan bahwa ketiga variable independen yaitu citra merek, persepsi kualitas, dan harga berpengaruh positif dan signifikan terhadap variable dependen, yaitu keputusan pembelian Mie Nges-Nges.

Hasil uji regresi berganda menunjukkan Bahwa semua variable independen (harga, lokasi, dan kualitas produk) pengaruh positif terhadap keputusan pembelian. 


\section{H3 : lokasi berpengaruh terhadap keputusan Pembelian kopi pada Coffe shop Komunal.}

\section{METODE PENELITIAN}

Jenis penelitian yang digunakan dalam penelitian ini adalah jenis penelitian asosiatif. Menurut Siliyanto (2006:70) penelitian asosiatif merupakan suatu penelitian yang bertujuan untuk mengetahui hubungan atau pengaruh. Antara variable independen adalah kualitas produk (X1), harga (X2), lokai (X3) terhadap variabel indepedent yaitu Keputusan Pembelian (

Lokasi penelitian dilakukan di Kota Mataram lebih tepatnya di Coffe Shop Komunal di Jalan Arif Rahman No.47, adapun alasan memilih lokasi penelitian di Coffe Shop Komunal Mataram yaitu karena terletak di ibukota dari provinsi NTB. Memiliki jumlah konsumen yang cukup banyak dan dirasa dapat untuk di jadikan sebagai sampel.

Populasi dalam penelitian ini adalah seluruh konsumen yang datang membeli coffe shop komunal.Metode pengumpulan data yang digunakan dalam penelitian ini adalah sampel survey, yang mana hanya sebagian dari populasi saja yang diambil untuk menentukan sampel yang diharapkan dapat mewakili populasi secara keseluruhan guna memperoleh gambaran yang cukup representatif. Metode ini dilakukan dengan cara membagikan kuisioner kepada responden. Karena jumlah populasinya tidak diketahui dengan jelas, maka dalam menentukan ukuran sampel digunakan pendapat Hair dalam Almanik (2008:40), yang menyatakan jika jumlah populasi tidak diketahui jumlahnya, maka aturan dasar dalam menentukan ukuran sampel adalah 5-20 kali jumlah variabel/indikator yang diteliti. karena jumlah indikator dalam penelitian ini adalah 14 indikator, untuk survei bisnis sampel sekitar 50 dianggap memadai maka jumlah sampel adalah $14 \times 5=70$ responden. Tehnik pengambilan sampel dengan teknik Accidental sampling.

Teknik pengambilan sampel dalam penelitian ini dilakukan dengan metode kebetulan (accidental sampling method). Menurut Ruslan (2004:156), Accidental sampling method adalah metode yang digunakan berdasarkan atas pemelihan sampel secara kebetulan. Pengambilan sampel seperti ini dilakukan terhadap siapa saja responden yang beretemu peneliti pada saat penelitian, bila di pandang responden yang bersangkutan dianggap cocok sebagai sumber data.

Dalam usaha pengumpulan data dan informasi yang diperlukan, penelitian ini menggunakan teknik pengumpulan Wawancara yaitupengumpulan data yang dilakukan dengan cara menanyakan beberapa pertanyaan yang terkait dengan penelitian ini pada konsumen yang membeli di Coffe Shop Komunal dan angke Yaitu pengumpulan data yang memberikan darft pertanyaan terkait dengan penelitian ini kepada konsumen yang membeli di Coffe Shop Komunal.

Alat pengumpulan data yang digunakan dalam penelitian ini adalah kuesioner. Kuesioner merupakan alat pengumpulan data yang berupa susunan pertanyaanpertanyaan yang bersifat tertutup dan harus diisi oleh responden dengan cara memilih salah satu alternatif jawaban yang tersedia agar peneliti dapat menganilis dari responden terhadap pengaruh produk, harga dan lokasi di Coffe Shop Komunal.

Jenis data yang digunaka dalam penelitian ini adalah data kuantitatif , ya itu data yang berupa angka-angka yang dapat dihitung dan diukur, berupa data yang berasal dari jawaban angket yang kemudian diberi skor untuk dihitung dengan alat analisis dan data Kualitatif, yaitu data yang menggunakan data tidak berbentuk angka-angka atau data yang dapat mencakup hampir semua data non- numerik yang 
biasanya data verbal yang diperoleh dari observasi dan wawancara yang menggunakan kata-kata untuk menggambarkan fakta dan fenomena yang diamati.

Sumber data penelitian ini adalah data primer, merupakan data yang diperoleh langsung dari objeknya yang didapatkan melalui para responden berdasarkan pertanyaan yang ada dan data sekunder, yang merupakan data yang telah diolah terlebih dahulu, yang diperoleh melalui buku-buku atau literatur-literatur mengenai permasalahan dalam penelitian ini.

\section{Uji Intrumen Penelitian Uji Validitas}

Uji Validitas yang dimaksudkan untuk menyatakan sejauh mana data yang tertampung pada suatu Kuisioner akan mengukur apa yang akan diukur. dalam penelitian ini akan mengukur mengenai kualitas produk dan desain produk terhadap keputusan pembelian. Adapun teknik korelasi product moment pada program SPSS for Windows. Menurut Sugiyono (2009:240), bila nilai $r$ terhitung lebih besar dari nilai $\mathrm{r}$ kritis ( $\mathrm{r}$ hitung $\geq 0,30$ ) maka instrument dikatakan valid, dan jika sebaliknya dikatakan tidak valid. Rumus korelasi product moment adalah sebagai berikut (Sugiyono, 2011:183).

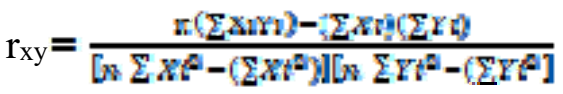

$$
\begin{aligned}
& \text { Dimana: } \\
& r=\text { Koefisien Korelasi Product Moment } \\
& \mathrm{n}=\text { Jumlah Subjek } \\
& \mathrm{Xi}=\text { Variabel Bebas } \\
& \mathrm{Yi}=\text { Variabel Terikat } \\
& \sum \mathrm{Xi}=\text { Jumlah Skor Item } \\
& \sum \mathrm{Xi}=\text { Jumlah Skor Total }
\end{aligned}
$$

\section{Uji Reliabilitas}

Reliabilitas adalah tingkat kemampuan instrument penelitian untuk mengumpulkan data secara tetap dari sekelompok individu (Sugiyono, 2009:273). Reliabilitas menunjukan konsistensi dan stabilitas hasil skala pengukuran tertentu. Pengujian reliabilitas ini dilakukan dengan menggunakan formula alfa pada program SPSS for Windows. Instrument dikatakan andal (reliable) bila memiliki koefisien reliabilitas sebesar 0,800 atau lebih, dapat diterima bila 0,610-0,790 bila kecil dari 0,600 maka dinyatakan tidak reliable (Sarwono,2006:228). Dalam penelitian ini digunakan formula alfa Cornbach dengan rumus sebagai berikut (Sugiyono,2005:109):

$$
\mathrm{r}=\frac{k}{k-1} 1-\frac{\sum s i^{2}}{s t^{2}}
$$

Dimana :

$$
\begin{array}{ll}
\mathrm{K} & =\text { Mean Kuadrat yang dicari } \\
\sum \mathrm{Si} & =\text { Mean Kuadrat kesalahan } \\
\mathrm{Si} & =\text { Varian total }
\end{array}
$$

\section{Uji Asumsi Klasik}

Sebelum dilakukan pengujian analisis regresi linier berganda terhadap hipotesis penelitian, maka terlebih dahulu perlu dilakukan suatu pengujian asumsi klasik atas data yang akan diolah sebagai berikut:

\section{Uji Multikolinearitas}


Uji multikolinieritas bertujuan untuk menguji apakah model regresi ditemukan adanya korelasi antar variabel bebas (independen) memiliki masalah multikorelasi (gejala multikolinearitas) atau tidak. Multikorelasi adalah korelasi yang sangat tinggi atau sangat rendah yang terjadi pada hubungan diantara variabel independen. Cara untuk mendeteksi adanya multikolinieritas dilakukan dengan cara meregresikan model analisis dan melakukan uji korelasi antar variabel independen dengan menggunakan variance inflation factor (VIF) dan nilai tolerance. Apabila nilai tolerancelebih besar dari 0,10 atau sama dengan nilai VIF kurang dari 10 maka tidak terdapat multikolinieritas dalam penelitian (Ghozali,2013).

\section{Uji Normalitas}

Uji normalitas bertujuan untuk menguji apakah dalam model regresi, variabel pengganggu atau residual memiliki distribusi normal (Ghozali,2013:160). Untuk mendeteksi normalitas data dilakukan dengan uji Kolmogorov-Smirnov. Dalam uji ini disimpulkan data terdistribusi normal secara multivariate, jika di dapat nilai signifikasi $>$ 0,05 ( Latan dan Temalagi, 2013:57).

\section{Alat Analisis}

Dalam upaya menjawab permasalahan dalam penelitian ini maka digunakan alat analisis data, sebagai berikut

\section{Analisis Regresi Linier Berganda}

Analisis regresi pada dasarnya adalah studi mengenai ketergantungan variabel dependen (variabel terikat) dengan satu atau lebih variabel independen (variabel penjelas/bebas), dengan tujuan untuk mengestimasi dan atau memprediksi ratarata populasi atau nilai rata-rata variabel dependen berdasarkan nilai variabel independen yang diketahui (Gujarati, 2003). Analisis regresi berganda ini merupakan analisis hubungan dua atau lebih variabel independen dengan variabel dependen. Penelitian ini menggunakan analisis regresi berganda sebagai alat analisis karena variabel yang diteliti mempunyai lebih dari satu variabel independen yaitu terdiri dari Produk(X1), Harga(X2), Lokai(X3) terhadap Keputusan Pembelian (Y). Dengan persamaan regresinya dapat dirumuskan sebagai berikut:

\section{Uji Hipotesis}

$$
\mathbf{Y}=\mathbf{a}+\mathbf{b} 1 \mathbf{x} 1+\mathbf{b} 2 \mathbf{x} 2+\mathbf{b 3} \mathbf{x}+\mathbf{e}
$$

Pengujian hipotesis merupakan suatu tahapan dalam proses penelitian dalam rangka menentukan jawaban apakah hipotesis ditolak atau diterima, untuk langkah uji hipotesis dilakukan sebagai berikut:

1. Uji t

Uji t pada menunjukkan pengaruh signifikansi variabel independen terhadap variabel dependen dan melihat pengaruhnya melalui nilai koefisien regresi. Pengambilan keputusan ini dilakukan berdasarkan perbandingan nilai signifikansi dari nilai $\mathrm{t}$ hitung masing-masing koefisien regresi dengan tingkat signifikansi yang telah ditetapkan, yaitu sebesar 5\% $(\alpha=0,05)$. Jika signifikansi t hitung lebih besar dari 0,05 , maka hipotesis nol (Ho) diterima yang artinya variabel tersebut tidak berpengaruh terhadap variabel dependen. Sedangkan jika signifikansinya lebih kecil dari 0,05, maka Ho ditolak yang artinya variabel independen berpengaruh terhadap variabel dependen.

2. Uji F

Uji F pada dasarnya dilakukan untuk melihat apakah model yang dianalisis memiliki tingkat kelayakan model yang tinggi yaitu variabel-variabel yang digunakan model mampu untuk menjelaskan fenomena yang dianalisis. Pengambilan keputusan 
dilakukan berdasarkan perbandingan nilai Fhitung dengan melihat tingkat signifikansinya, kemudian membandingkan dengan taraf signifikansi yang telah ditetapkan (5 persen atau 0,05$)$.

3. Koefisien Determinasi $\left(\mathrm{R}^{2}\right)$

Koefisien determinasi ( $\mathrm{R}^{2}$ ) digunakan untuk mengetahui seberapa jauh kemampuan model dalam menerangkan variasi variabel dependen (Ghozali, 2011). Nilai koefisien determinasi $\left(\mathrm{R}^{2}\right.$ ) antara $0(\mathrm{nol})$ dan 1 (satu). Nilai $\left(\mathrm{R}^{2}\right)$ yang kecil berarti kemampuan variabel-variabel independen dalam menjelaskan variasi variabel dependen amat terbatas dan sebaliknya jika nilai yang mendekati 1 (satu) berarti variabel-variabel independen memberikan hampir semua informasi yang dibutuhkan memberikan hampir semua informasi yang dibutuhkan untuk memprediksi variabelvariabel depen.

\section{HASIL DAN PEMBAHASAN}

\section{Uji Validitas}

Uji validitas dimaksudkan untuk menyatakan sejauhmana data yang tertampung pada suatu kuesioner dalam mengukur apa yang diukur. Merujuk pada hasil dari uji validitas yang sudah dilakukan bahwa, semua instrument mulai dari Varibel Produk (X1) yang terdiri dari $\mathrm{x} 1.1$, x1.2, x1.3, dan xI.4 semuanya menghasilkan nilai rHitung $>$ daripada rTabel, selain itu Variabel Harga(X2) yang terdiri dari $\mathrm{x} 2.1, \mathrm{x} 2.2, \mathrm{x} 2.3, \mathrm{x} 2.4$ semuanya menghasilkan nilai rHitung $>$ daripada rTabel, selain itu Variabel Harga(X2) yang terdiri dari x3.1, x3.2, x3.3, x3.4 semuanya menghasilkan nilai rHitung $>$ daripada rTabel dan yang terakhir adalah variabel Keputusan Pembelian (Y) yang terdiri dari y1, y2, y3, y4,y5 semuanya menghasilkan nilai rHitung $>$ daripada rTabel. Sehingga dapat disimpulkan bahwa semua instrument dalam penelitian ini dapat dikatakan valid.

\section{Uji Realiabilitas}

Tabel 2.

Hasil Uji Realiabilitas

\begin{tabular}{lccc}
\hline \multicolumn{1}{c}{ Variabel } & $\begin{array}{c}\text { Cronbachs } \\
\text { Alpha }\end{array}$ & Kriteria & Keterangan \\
\hline Produk (X1) & 0,901 & 0,6 & Reliabel \\
Harga (X2) & 0.865 & 0,6 & Reliabel \\
Tempat(X3) & 0,820 & 0,6 & Reliabel \\
Keputusan Pembelian (Y) & 0,929 & 0,6 & Reliabel \\
\hline
\end{tabular}

Berdasarkan pada tabel 2 menunjukkan bahwa semua nilai koefisien Alpha Cronbach pada Variabel Produk, Harga, Tempat dan Keputusan Pembelian memiliki nilai lebih besar dari 0,6 , sehingga dapat dinyatakan reliabel.

\section{Uji Normalita}

Berdasarkan hasil uji normalitas yang telah dilakukan, diketahui nilai signifikansi $0,142>0,05$ maka dapat disimpulkan bahwa data penelitian masing-masing variabel berdistribusi normal, karena memiliki nilai signifikansi yang lebih besar dari pada 0,05 .

\section{Uji Asumsi Klasik}


Pada penelitian ini dilakukan dengan uji multikolinearitas dan uji linearitas sebagai berikut:

1. Uji Multikolinearitas

Uji ini digunakan untuk menguji ada tidaknya hubungan antar variabel bebas dan untuk menguji apakah dalam persamaan regresi ditemukan adanya korelasi antar variabel bebas (independen). Di dalam model regresi dapat dilihat dari nilai tolerance dan lawan Variance Inflation Factor (VIF). Nilai cut off yang umum dipakai untuk menunjukkan adanya multikolinearitas adalah nilai tolerance $>0,10$ atau nilai VIF $<10$ dengan tingkat kolonieritas 0,50, dan iktisar hasil multikolinieritas pada variabel bebasDari hasil perhitungan yang ada pada tabel 4.5. hasil uji multikolinearitas, variabel bebas menunjukkan bahwa nilai VIF $=3.191$, $4.313,3.235$ dimana hasil tersebut lebih kecil dari 10. Sehingga dapat disimpulkan bebas dari multikolinearitas.

2. Uji Linearitas

Pengujian Linearitas regresi dilakukan dengan uji Statistik F. Dua variabel dikatakan mempunyai hubungan yang linier bila signifikansi lebih besar dari 0,05 . Hasil uji linieritas untuk masing-masing variabel dapat dilihat pada tabel berikut ini:

Tabel 3.

Hasil Uji Linearitas

\begin{tabular}{cccc}
\hline Variabel & F hitung & p value & Keterangan \\
\hline X1 dengan Y & 1.410 & 0.211 & Linear \\
X2 dengan Y & 1.562 & 0.148 & Linear \\
X3 dengan Y & 1.770 & 0.110 & Linier \\
\hline
\end{tabular}

Berdasarkan tabel diatas hasil uji linearitas diketahui nilai Sig. devitation from linearity pada X1 (produk) sebesar 0,211 >0,05, X2 (harga) sebesar 0,148 >0,05 dan X3 (lokasi) $0,110>$ ) 0,05, maka dapat disimpulkan bahwa terdapat hubungan yang linear antara kualitas produk dengan keputusan pembelian, begitu juga dengan desain produk dengan keputusan pembelian.

\section{Persamaan Regresi Linier Berganda}

Hasil analisis linier berganda dapat dilihat pada tabel 4.

Tabel 4.

Analisis Regresi Berganda

\begin{tabular}{ccccc}
\hline Variabel & B & Std. Error & T & Sig. \\
\hline Konstanta & 1.380 & 1.149 & 1.201 & 0.234 \\
Produk & 0,414 & 0,117 & 3.548 & 0,001 \\
Harga & 0,595 & 0,141 & 4.213 & 0,000 \\
Lokasi & 0,175 & 0,127 & 1.375 & 0,174 \\
R & 0,809 & Fhitung & 90.834 & \\
R2 & 0,805 & Probabilitas F & 0.00 & \\
Adjusted R2 & 0,796 & & & \\
\hline
\end{tabular}

Berdasarkan Tabel 4 di atas persamaan regresi linier berganda dapat disusun sebagai berikut 
$\mathrm{Y}=1.380+0,414 \mathrm{X}_{1}+0,595 \mathrm{X}_{2}+0,175 \mathrm{X}_{3}$

Keterangan:

$\mathrm{Y}=$ Keputusan Pembelian

$\mathrm{X}_{1} \quad=$ Produk

$\mathrm{X}_{2}=$ Harga

$\mathrm{X}_{3+} \quad=$ Lokasi

$\mathrm{T}$ tabel $=\mathrm{t}(\mathrm{a} / 2 ; \mathrm{n}-\mathrm{k}-1)=(0,025 ; 66)=1998$

$\mathrm{F}$ tabel $=\mathrm{F}(\mathrm{k} ; \mathrm{n}-\mathrm{k})=\mathrm{F}(3 ; 68)=2,74$

Berdasarkan persamaan regresi linier berganda diatas dapat diinterpretasikan sebagai berikut:

1. Konstanta bernilai positif sebesar 1.380. Hal ini menunjukkan bahwa apabila variable produk, harga dan lokasi berpengaruh positif terhadap keputusan pembelian, maka besarnya rata-rata keputusan pembelian pembelian sebesar 1.380.

2. Koefisien regresi variabel produk bernilai positif sebesar 0.414 . Hal ini berarti jika variabel produk ditingkatkan 1 satuan maka akan meningkatkan keputusan pembelian sebesar 0,414.

3. Koefisien regresi variabel harga bernilai positif sebesar 0.595 . Hal ini berarti jika variabel harga ditingkatkan 1 satuan maka akan meningkatkan keputusan pembelian sebesar 0.595 .

4. Koefisien regresi variabel lokasi bernilai positif sebesar 0.175 . Hal ini berarti jika variabel harga ditingkatkan 1 satuan maka akan meningkatkan keputusan pembelian sebesar 0.175 .

\section{Uji t}

Uji statistik $\mathrm{t}$ digunakan untuk mengetahui apakah suatu variabel secara parsial berpengaruh nyata atau tidak.penjelasan untuk uji $t$ pada masing-masing variabel independen adalah sebagai berikut:

1. Variabel Produk

Produk memiliki tingkat signifikansi 0,001. Dari hasil uji t pada variabel kualitas produk menyatakan bahwa signifikansi uji t lebih kecil dari 0,05 dan koefisien regresi mempunyai nilai positif sebesar 0,414 . Sedangkan nilai thitung yang dieperoleh yaitu 3.548 lebih besar dari nilai tabel yaitu 1.998. Berdasarkan hasil tersebut maka hipotesis menyatakan "Semakin baik kualitas produk maka semakin tinggi keputusan Pembelian".

2. Variabel Harga

Harga memiliki tingkat signifikansi 0,000. Dari hasil uji t pada variabel harga menyatakan bahwa signifikansi uji t lebih kecil dari 0,05 dan koefisien regresi mempunyai nilai positif sebesar 0,595 . Sedangkan nilai thitung yang dieperoleh yaitu 4.213 lebih besar dari nilai tabel yaitu 1.998. Berdasarkan hasil tersebut maka hipotesis menyatakan "Semakin terjangkau harga yang diciptakan perusahaan maka semakin tinggi keputusan pembelian".

3. Variabel Lokasi

Lokasi memiliki tingkat signifikansi 0,174. Dari hasil uji t pada variabel lokasi menyatakan bahwa signifikansi uji t lebih besarl dari 0,05 dan koefisien regresi mempunyai nilai positif sebesar 0,175 . Sedangkan nilai thitung yang dieperoleh yaitu 1.375 lebih kecil dari nilai tabel yaitu 1.998. Berdasarkan hasil tersebut maka 
hipotesis menyatakan "lokasi berpengaruh terhadap keputusan pembelian, tetapi tidak signifikan .

\section{Uji F}

Dari hasil Uji F diperoleh nilai Fhitung sebesar 99.834 dan nilai $\mathrm{F}_{\text {tabel }}$ sebesar 2.74. Sedangkan seignifikansinya sebesar 0,000 . Karena nilai signifikansi dibawah 0,05 dan nilai Fhitung lebih besar daripada nilai $\mathrm{F}_{\text {tabel }}(99.834>2.74)$, maka model regresi dapat digunakan untuk memprediksi keputusan pembelian atau dapat dikatakan bahwa produk, harga dan lokasi layak untuk menjelaskan variabel perilaku keputusan pembelian.

\section{Uji Koefisien Determinasi $\left(\mathbf{R}^{2}\right)$}

Koefisien Determinasi $\left(\mathrm{R}^{2}\right)$ digunakan untuk mengukur seberapa jauh kemampuan model regresi dalam menerangkan variabel-variabel dependen (Ghozali,2011:97).

Berdasarkan uji Determinasi yang telah dilakukan, menunjukkan bahwa model summary besarnya $\mathrm{R}^{2}$ adalah 0,805 , hal ini berarti 80,5 persen variabel keputusan pembelian dapat dijelaskan oleh variasi dari kedua variabel independen yakni produk, harga dan lokasi. Sedangkan sisanya $(100 \%-80,5 \%=19,5 \%)$ dipengaruhi oleh variabel lain di luar penelitian.

Sedangkan hasil uji hipotesis menunjukkan bahwa terdapat hubungan yang positif dan signifikan variabel kualitas produk terhadap keputusan pembelian dengan nilai signifikansi $0,141<0,05$ dan thitung $=3.548>$ tabel $=1.998$. Hal ini menunjukkan bahwa apabila kualitas produk ditingkatkan, maka akan keputusan konsumen untuk melakukan pembelian juga akan meningkat. Hasil uji hipotesis harga menunjukkan bahwa terdapat hubungan yang positif dan signifikan terhadap keputusan pembelian dengan nilai signifikansi $0,595<0,05$ dan thitung $=4.213>$ tabel $=1.998$. Hal ini menunjukkan bahwa apabila nilai dari harga ditingkatkan , maka keputusan pembelian akan meningkat. Begitu pula dengan hasil uji hipotesis lokasi menunjukkan bahwa terdapat hubungan yang positif dan tidak signifikan terhadap keputusan pembelian nilai signifikansi $0,175<0,05$ dan thitung $=1.375>t_{\text {tabel }}=1.998$. Hal ini juga berarti apabila lokasi mudah akses dan tempat yg menarik ditingkatkan , maka keputusan pembelian juga akan meningkat walaupun pengaruhnya tidak berarti.

Hasil penelitian ini sejalan dengan teori yang dikemukan oleh Sumarwan (2011), dimana keputusan pembelian merupakan suatu keputusan sebagai pemilihan suatu tindakan dari dua atau pilihan alternatif, yaitu mempertimbangkan faktor-faktor kualitas produk, harga dan lokasi. Hal ini diperkuat juga dengan penelitian yang telah dilakukan Junio Andreti, Nabila H Zhafira Vol. 2, No.6, 2013, 72-78 The Analysis of Produk, Price, Place, Promotion and Service Quality on Customers'Buying Decision of Convenience Store : A Survey of Young Adult in Bekasi, West Java.

\section{KESIMPULAN DAN SARAN}

\section{Kesimpulan}

Kesimpulan yang dapat ditarik dari penelitian ini adalah sebagai berikut:

1. Produk berpengaruh positif dan signifikan terhadap Keputusan Pembelian kopi pada Coffee Shop Komunal. Artinya bahwa apabila produk ditingkatkan maka keputusan pembelian juga akan meningkat. Sehingga produk dapat memberikan pengaruh terhadap konsumen untuk melakukan keputusan pembelian. 
2. Harga berpengaruh positif dan signifikan terhadap keputusan pembelian kopi pada Coffee shop Komunal. Artinya bahwa apabila harga terjangkau dan sering memberikan promo-promo menarik pada Coffee Shop Komunal, maka keputusan pembelian juga akan meningkat. Sehingga harga dapat memberikan pengaruh terhadap konsumen untuk melakukan KeputusanPembelian.

3. Lokasi berpengaruh positif dan tidak signifikan terhadap keputusan pembelian kopi pada Coffee Shop Komunal. Artinya bahwa apabila lokasi mudah akses dan tempat yang menarik ditingkatkan pada Coffee Shop Komunal, maka keputusan pembelian juga akan meningkat. Sehinnga lokasi dapat memberikan pengaruh terhadap konsumen untuk melakukan KeputusanPembelian.

\section{Saran}

1. Perusahaan Coffee Shop Komunal diharapkan dapat lebih memperhatikan lagi strategi produk yang dilakukan, baik dari segi pemasarannya itu sendiri. Karena dari hasil penelitian menyimpulakan bahwa kualitas produk merupakan variabel pendukung yang baik untuk menarik konsumen sehingga perusahan diharapkan dapat lebih dapat meningkatkan kualitas produknya yang lebih baik dari pada produk yang telah dilakukan sebelumnya.

2. Meskipun harga pada Coffee Shop Komunal sudah cocok dan terjangkau menurut pelanggan, tetapi akan jauh lebih baik lagi jika Coffee Shop Komunal sering mengadakan promo atau event, agar lebih menarik dan dapat membuat konsumen merasa puas, karena harga terjangkau dan sering memberikan promo merupakan faktor pendukung yang baik untuk menarik pelanggan untuk melakukan keputusan pembelian.

3. Walaupun lokasi pada Coffe shop Komunal sudah mudah akses, terjangkau dan menarik menurut pelanggan, tetapi akan jauh lebih baik lagi jika Coffe shop Komunal sesekali mengubah interior atau memberikan suasan berbeda sehingga , agar lebih menarik dan dapat membuat konsumen merasa puas dan merasakan suasana berbeda.

\section{REFERENSI}

Alferd, Owusu. 2013. Influences of Price And Quality On Consumer Purchase Of Mobile Phone In The Kumasi Metropolis In Ghana A Comparative Study. European Journal of Business and Management Vol.5, No.1

Alma, Buchari. 2006. Pemasaran dan Pemasaran Jasa. Bandung:

Alfabeta. Andreti, J dan Zhafira, Nabila H. 2013. The Analysis of Product, Price, Place,Promotion and Service Quality on Customers' Buying Decision of Convenience Store: A Survey of Young Adult in Bekasi, West Java, Indonesia. International Journal of Advances in Management and Economics. Vol. 2, No.6

Anwar, Sanusi. 2014. Metodologi Penelitian Bisnis. Cetakan Ketiga. Jakarta: Salemba Empat.

Effendy, Onong Uchjana. 2008. Dinamika Komunikasi. Bandung: PT. Remaja.Rosdakarya. 
Ghanimata, Fifyanita. 2012. Analisis Pengaruh Harga, Kualitas Produk dan Lokasi terhadap Keputusan Pembelian (Studi pada Pembeli Produk Bandeng Juwana Elrina Semarang). Jurnal Manajemen Vol.1, No.2. Fakultas Ekonomi Universitas Diponegoro

Ghozali, Imam. 2011. Aplikasi Analisis Multivariate Dengan Program SPSS. Semarang: Badan Penerbit Universitas diponegoro.

Gujarati, Damodar. 2010. Ekomomika Dasar. Jilid 1. Edisi 5. Salemba Empat Jakarta.

Iskandar. 2009. Metodologi Penelitian Kualitatif. Jakarta: Gaung Persada Press.

Kanoga, S. Njugana, R. dan Bett S. 2015. The Effect of Place on Performance of Shopping Malls in Nairobi County Kenya. Journal of Social Sciences and Humanities Vol. 1, No. 4.

Kotler, Philip dan Amstrong 2012, Dasar-Dasar Pemasaran. Jilid 1. Edisi Tiga Belas. Jakarta: Erlangga. 